\title{
PROBABILISTIC HEALTH RISK ASSESSMENT DUE TO NATURAL FORMALDEHYDE INTAKE THROUGH OPAH FISH (Lampris guttatus) CONSUMPTION IN INDONESIA
}

\author{
Ajeng Kurniasari Putri', Umi Anissah', Farida Ariyani' ${ }^{1}$, and Singgih Wibowo ${ }^{1}$ \\ ${ }^{1)}$ Research and Development Center for Marine and Fisheries Product Processing and Biotechnology \\ JI. KS. Tubun Petamburan VI, Jakarta 10260 Indonesia \\ Article history: \\ Received: 2 May 2018; Revised: 21 July 2018; Accepted: 27 August 2018
}

\begin{abstract}
Opah fish (Lampris guttatus) is one of the bycatch products of Tuna fish catch. The fish currently has become one of the major exported commodities of Indonesia. However, due to its natural deterioration, the fish contained high formaldehyde up to $200 \mathrm{ppm}$ which can be one of health risk when consumed. The aim of this study is to obtain probabilistic health risk assessment data due to consumption of opah fish that contaminated with natural formaldehyde. The study was initiated with analyzing the formaldehyde content of the opah fish (Lampris guttatus) stored in freezing temperature for less than three months. To evaluate the population risk associated with consumption of formaldehyde-contaminated fish, a probabilistic exposure assessment was conducted in several categories based on individual characters who are likely to consume opah fish. Exposures are grouped by sex (male and female) and age (children and adults). To identify the best fit distribution in the probabilistic exposure analysis, fish consumption, body weight and natural occurrence of formaldehyde concentration in Opah fish were fitted in the @Risk®7.0 for Microsoft Excel 2010. Risk exposure analysis was conducted based on the formaldehyde content in Opah fish (real concentration) and two other scenarios of 2 and 4 times of the Opah fish real formaldehyde content. The result showed that Opah fish caught in Indonesian waters and stored in freezing temperature for less than three months, due to deterioration process, could naturally produce formaldehyde ranged from 4,62 $\pm 0,00 \mathrm{mg} / \mathrm{kg}$ to $58,10 \pm 0,46 \mathrm{mg} / \mathrm{kg}$. Consequently, based on the probabilistic exposure assessment, female children in Jakarta and Surabaya were considered as in health risk problems. Extremely, the further simulations using two and four times of formaldehyde concentration exposure revealed the health risk for both gender and all age groups of Jakarta and Surabaya residents. Therefore, the stakeholders i.e. government and policy makers should take some priorities in formulating a proper risk management strategy on the basis of knowledge of endogenous formaldehyde present in Opah fish as well as risk management strategies for the fish consumer in Indonesia.
\end{abstract}

Keywords: exposure, formaldehyde, health risk assessment, opah fish, simulation

\section{Introduction}

Indonesia has been known for its large fisheries catch and recently became one of the biggest fish exporter in the world. As important part of food and nutrition, fish has to be guaranteed and to be ensured safe from harmful elements for health (M. S. Hoque et al., 2018). Unfortunately, several fish have been contaminated by hazardous substances. Those substances could be naturally formed due to metabolism reaction. One of those substances is formaldehyde. Time and way of storage are factors that lead to an increase of formaldehyde content for each type of fish (Yeh, Lin, Chen, \& Wen, 2013); Murtini et al., 2014, Rachmawati, Riyanto, \& Ariyani, 2007).

The content of formaldehyde in fish endanger health because it is carcinogenic, allergenic and induce genotoxicity (M. S. Hoque, Jacxsens, De Meulenaer, \& Alam, 2016). Health problems that occured due to formaldehyde including acute toxicity and immunotoxicity, chronic toxicity, hematotoxicity, reproductive toxicity and carcinogenesis (Tang et al.,

${ }^{*}$ Corresponding author.

E-mail: ajengkp@gmail.com 
2009). Formaldehyde is classified as category I compound that could cause cancer in humans and could enter the human body through the mechanism of inhalation, oral and skin contact (IARC, 2012).

Indonesia, through Permenkes Number 033 / Menkes / Per / VII / 2012, has been regulating the distribution of food that does not meet the requirements of safety and quality for health including prohibited the use of formaldehyde as food additives. Moreover, the US Environmental Protection Agency (US EPA) established oral reference dose (Rfd) formaldehyde at a dose of $0.2 \mathrm{mg} / \mathrm{kg}$ body weight/ day (Wang, Cui, \& Fang, 2007), while the International Program on Chemical Safety (IPCS) stipulates that the safe limit of exposure to formaldehyde contained in food and entry into the human body is $1.5 \mathrm{mg} /$ day to $14 \mathrm{mg} /$ day for adults. China established a maximum content of formaldehyde in fermented vegetables of $2 \mathrm{mg} / \mathrm{L}$ (Tang et al., 2009). Eating foods exposed to formaldehyde in acute form might cause disturbances in the respiratory system, digestion and irritation of the skin and eyes, while chronically it might cause cancer, especially tracheal and pancreatic cancer, and even it might cause death (Abdollahi \& Hosseini, 2014;Bhowmik, Begum, Hossain, Rahman, \& Alam, 2017; IARC Working Group on the Evaluation of Carcinogenic Risks to Humans, 2012; Mundt, Gentry, Dell, Rodricks, \& Boffetta, 2018).

An example of fish which may contain a high level of formaldehyde is opah fish. Opah fish was originally captured as bycatch in Tuna fisheries (Murtini, Ariyani, $\mathrm{t}$ al., 2017). During 2015-2017, opah fish that was captured reached 573,44 ton which $70,90 \%$ of it was consumed domestically in Indonesia, meanwhile the rest of the fish was exported to Malaysia, Mauritius, Japan, Taiwan and USA (BKIPM, 2017). Opah fish is indicated to has a high natural formaldehyde content. Moreover, its natural formaldehyde content is increasing during frozen storage (Murtini, Ariyani, et al., 2017). The natural formaldehyde content in opah fish has potential to cause health problems whenever be consumed. However, there are only few reliable reports and information regarding to health problem risk of exposure of formaldehyde-contaminated opah fish.

Thus, this study presents the level of health risk due to consumption of opah fish that contaminated with natural formaldehyde due to deterioration process. The results are expected to provide an overview of the influence of opah fish consumption with a high content of natural formaldehyde in Indonesia, also might be used as a reference for policy holders to establish regulations on food consumption in stress of handling process also time, especially for the food that has natural formaldehyde content.

\section{Material and Methods}

\subsection{Study Site and Sample Collection}

Four freshly captured of opah fish (Lampris guttatus) with average weight of $18.57 \pm 3.14 \mathrm{~kg}$; and TVB content of $<30 \mathrm{mgN} \%$ were kept in freezing condition for 1 week by KM Perintis Jaya 88. The opah fish sampling location was at coordinates $17^{\circ}$ 32 ' 0 "LS and $111^{\circ} 20^{\prime}$ ' 0 " BT also $17^{\circ} 33$ ' 0 "and $111^{\circ}$ $18^{\prime} 0$ " BT. The samples were transported to the laboratorium of Research Center for Marine and Fisheries Product Processing and Biotechnology (RCMFPPB) in Jakarta, cut and divided into four groups as replicates before frozen stored $\left(-18^{\circ} \mathrm{C}\right)$ for three months depending on their TVB content. During the storage (less than three months), formaldehyde content of seven opah fish (with a weight range of $2,65 \pm 0,45 \mathrm{~kg}$ ) that categorized as fresh (TVB $<30$ $\mathrm{mgN} \%$ ) were obtained.

\subsubsection{Chemicals}

The chemicals used in the research were boric acid (Merck), Trichloroacetic acid (TCA; Merck); acetylacetone (Merck); ammonium acetate (Merck); glacial acetic acid (Merck); Hydrochloric acid (Merck), calcium carbonate (Merck), Nash's reagent, and 100 ppm formaline standard solution which was prepared from $37 \%$ formaldehyde solution (Merck) with titration acid-base method according to Farmakope Indonesia (Rohmad, Putri, Anissah, \& Murtini, 2018).

\subsubsection{Determination of Formaldehyde Concentration using spectrophotometry}

The analysis of the natural formaldehyde content was conducted using UV-Vis Spectrophotometric (Perkin Elmer, ) instrument at $412 \mathrm{~nm}$ wavelength according to (Benjakul, Visessanguan, \& Tanaka, 2004; Rohmad, Putri, Anissah, \& Murtini, 2018). The spectrophotometric method using Nash's reagent was applied to determine the formaldehyde content (mg/ $\mathrm{kg}$ ) in fish. Nash's Reagent was used as an indicator which helps to detect the absorbance of formaldehyde (Nash, 1953). To prepare Nash's reagent, $15 \mathrm{~g}$ ammonium acetate was diluted in a $100 \mathrm{ml}$ Erlenmeyer flask with an addition of $0.3 \mathrm{ml}$ of acetylacetone and $0.2 \mathrm{ml}$ of acetic acid. About $30 \mathrm{~g}$ fish flesh was blended for 10 minutes. Sixty $(60) \mathrm{mL}$ of $6 \% \mathrm{w} / \mathrm{w}$ TCA was added for extraction of formaldehyde from the fish flesh. The extracted solution was then filtered by a Whatman No. 1 filter paper. The $\mathrm{pH}$ of the solution was determined by a $\mathrm{pH}$ meter. The addition of TCA resulted in a reduced $\mathrm{pH}$ value of the sample which was then adjusted between $6.00-6.50$ by using potassium hydroxide $(\mathrm{KOH})$ and hydrochloric acid $(\mathrm{HCl})$. Five (5) 
$\mathrm{mL}$ of the sample solution was taken in a $50 \mathrm{~mL}$ volumetric/conical flask. The sample was taken out and $2 \mathrm{~mL}$ of previously prepared Nash's reagent was added as an indicator. The fish sample was then heated in the water bath at $60^{\circ} \mathrm{C}$ for 30 minutes. The absorbance of the sample in a cuvette was measured at $412 \mathrm{~nm}$ immediately by UV/Vis spectrophotometer. The sample reading (triplicate) was placed in the standard curve for the calculation of formaldehyde concentration in the fish sample.

\subsection{Collection of Fish Consumption and Body Weight Data}

\subsubsection{The data of opah fish consumption}

Currently, the data of opah fish consumption by Indonesian is not available. However, in this research, the data of opah fish consumption were obtained through secondary data approach which is issued by a couple of government agencies. The calculation of consumption data is approximated by secondary data processing that issued by Fish Quarantine Agency and Quality Supervisor (BKIPM) through Statistics BKIPM (BKIPM, 2018) and the Indonesia Ministry of Health through the results of the Individual Food Consumption Survey of 2014 (Siswanto, 2014). Based on these approaches, a number of opah fish that consumed by the domestic community (Indoneesian) can be obtained. The number of opah fish catches used for subsequent domestic consumption is compared with the number of residents according to the established category (child, adult, male and female) in the area. The result obtained is the possibility of opah fish consumption in units ( $\mathrm{g} /$ day).

Opah fish data entry at fish quarantine stations in all regions of Indonesia 2015-2017 (BKIPM, 2018) showed that the Opah fish caught in Indonesian waters was used for both domestic consumption and for export commodity. For domestic distribution, it was recorded that the fish was only landed in the Benoa, Bali Fish Quarantine Unit for BKIPM Class I Surabaya and BKIPM Class I Jakarta II. As for export needs, Opah fish is delivered through BKIPM Class I Jakarta II, KIPM Station Class I Medan II, BKIPM Class I Surabaya I and BKIPM Class I Denpasar. Based on the data of domestic fish shipment destination, the exposure assessment calculation of the opah fish consumption was conducted at DKI Jakarta and East Java Provinces. Then it was assumed that Opah fish was distributed for public consumption in both provinces. The flow chart of the determination of Opah fish consumption was described in Figure 1.

\subsubsection{Weight data}

Response to contaminant exposure in each individual is more affected by weight. Based on this, the calculation of formaldehyde exposure is differentiated by 4 categories, ie. boys, girls, adult males and adult females. Body weight data for the four categories are based on Muljati, Triwinarto, Utami, Penelitian, \& Hermina (2016). Body weight data by sex and age group is used to determine the minimum, mean and maximum weight values for categories of children and adults of both men and women as described in Figure 2.

\subsection{Probabilistic Exposure Assessment}

To evaluate the population risk associated with consumption of formaldehyde-contaminated fish, a probabilistic exposure assessment was conducted. Exposure assessment for the calculation of probabilistic risk assessment due to natural formaldehyde in opah Fish intake is conducted in several categories. Individual characters who are likely to consume opah fish are grouped by sex (male and female) and age (children and adults). This categorization is done based on the body weight difference. This weight difference is one of the factors that influence the body's response when receiving exposure to harmful substances, in this study was formaldehyde.

@Risk®7.0 for Microsoft Excel 2010, Palisade (2010), was used to analyze the Opah fish consumption data (g/day BW) combined with formaldehyde concentration $(\mathrm{mg} / \mathrm{kg}$ ) distributions data which resulted an exposure distribution data $(\mathrm{mg} / \mathrm{kg}$ BW.d). Best fit distributions of opah fish consumption and formaldehyde concentration was analyzed using the Chi-square statistics. First-order Monte-Carlo simulations were undertaken considering 50,000 iterations. The simulations were repeated three times to ensure a stable estimation. Formaldehyde intake (mean, standard deviation, maximum, minimum) was determined from the output of the simulation model. (M. d. S. Hoque et al., 2018)

Formalin dietary exposure in the flesh of Opah fish included the consumptions and three different scenarios of formaldehyde concentration (real concentration, 2 and 4 times of real concentration) data were analyzed. Risk exposure analysis was done based on the available data of formaldehyde concentration in fish $(\mathrm{mg} / \mathrm{kg})$ and average fish consumption ( $\mathrm{g} /$ day/person) which then was calculated as per following equation. Exposure 


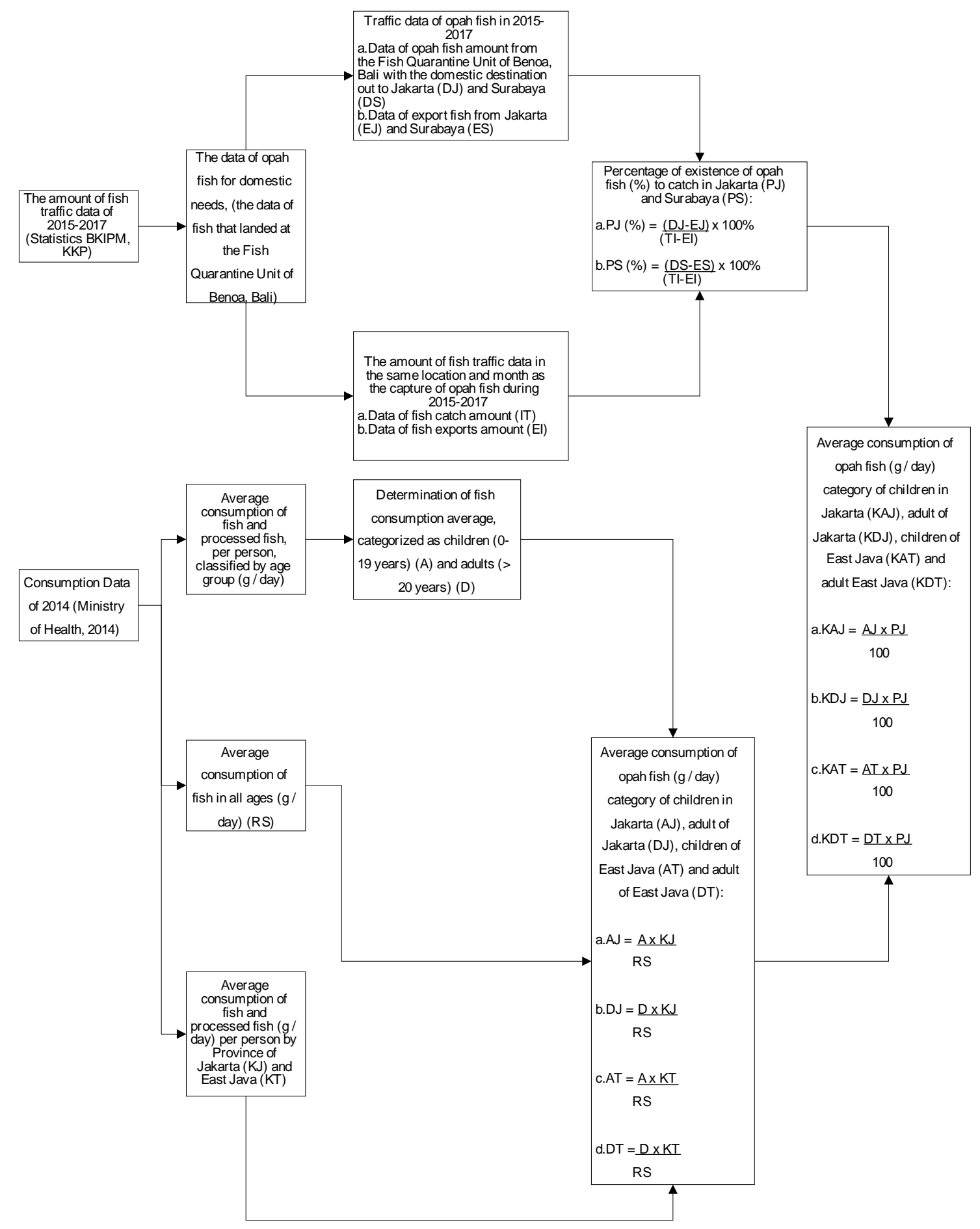

Figure 1. Flowchart method of the opah fish consumption determination in Jakarta and Surabaya categorized by age and sex.

expressed as $\mathrm{mg} / \mathrm{kg}$ body weight/day (M. S. Hoque et al., 2016). Concentration of contaminant $(\mathrm{mg} / \mathrm{kg}) X$ consumption (g/day)

Exposure $=\frac{\text { Concentration of contaminant }(\mathrm{mg} / \mathrm{kg}) \times \text { Consumption }(\mathrm{g} / \text { day })}{\mathrm{aody} \text { Weight }(\mathrm{kg})}$

\section{Results and Discussion}

\subsection{Prevalence and Concentration of Natural Formaldehyde in Opah fish from Indonesia}

The natural formaldehyde content in Opah fish is shown in Table 1. Based on the result, natural 
Table 1. Formaldehyde concentration $(\mathrm{mg} / \mathrm{kg}$ ) in Opah fish (Lampris guttatus) along with a variation of two times and four times of formaldehyde real concentration

\begin{tabular}{|c|c|c|c|}
\hline Fish species & $\begin{array}{c}\text { Formaldehyde content } \\
\text { (real) } \\
(\mathrm{mg} / \mathrm{kg}) \pm \mathrm{SD}\end{array}$ & $\begin{array}{l}\text { Simulation of } 2 \text { times of } \\
\text { FA real concentration } \\
(\mathrm{mg} / \mathrm{kg}) \pm \mathrm{SD}\end{array}$ & $\begin{array}{l}\text { Simulation of } 4 \text { times of FA real } \\
\text { concentration }(\mathrm{mg} / \mathrm{kg}) \pm \mathrm{SD}\end{array}$ \\
\hline \multirow[t]{7}{*}{$\begin{array}{c}\text { Opah fish flesh (Lampris guttatus), } \\
\text { weight range } 2.65 \pm 0.45 \mathrm{~kg} \text {, TVB } \\
<30 \mathrm{mg} \mathrm{N} \%\end{array}$} & $4.62 \pm 0.00$ & $9.24 \pm 0.00$ & $18.48 \pm 0.00$ \\
\hline & $8.21 \pm 0.52$ & $16.41 \pm 1.04$ & $32.83 \pm 2.07$ \\
\hline & $14.80 \pm 0.76$ & $29.60 \pm 1.53$ & $59.20 \pm 3.06$ \\
\hline & $27.82 \pm 0.14$ & $55.63 \pm 0.28$ & $111.27 \pm 0.56$ \\
\hline & $32.68 \pm 1.66$ & $65.35 \pm 3.32$ & $130.70 \pm 6.64$ \\
\hline & $36.44 \pm 0.83$ & $72.88 \pm 1.66$ & $145.76 \pm 3.32$ \\
\hline & $58.10 \pm 0.46$ & $116.19 \pm 0.91$ & $232.38 \pm 1.83$ \\
\hline Opah Fish (Lampris guttatus) & 91 & & \\
\hline $\begin{array}{l}\text { Opah Fish (Lampris guttatus), } \\
\text { frozen storage up tp } 6 \text { months }\end{array}$ & 250 & & \\
\hline
\end{tabular}

${ }^{*}$ FA stands for Formaldehyde. $\mathrm{N}=3$

Sources: (Anonymous, 2016a; Anonymous, 2016b; Anonymous, 2016c); Murtini et al., (2017)

formaldehyde content of Opah fish was ranged from $4,62 \pm 0,00 \mathrm{mg} / \mathrm{kg}$ to $58,10 \pm 0,46 \mathrm{mg} / \mathrm{kg}$. The results was obtained from fresh Opah fish flesh (Lampris guttatus) with weight range of 2,65 $\pm 0,45 \mathrm{~kg}$. The freshness of Opah fish was monitored through its TVB content which should less than $30 \mathrm{mg} \mathrm{N} \%$. This finding is in agreement with another study, Murtini et al., (2017) stated that the natural formaldehyde concentration in fresh Opah fish could reach $40 \mathrm{mg} /$ $\mathrm{kg}$. The result is also has similarity with other study of natural formaldehyde in fish that ranged from 10.8 $\pm 1.72 \mathrm{mg} / \mathrm{kg}-39.68 \pm 7.87 \mathrm{mg} / \mathrm{kg}$ for marine finfish and ranged from $6.4 \pm 1.2 \mathrm{mg} / \mathrm{kg}$ to $293 \pm 26 \mathrm{mg} / \mathrm{kg}$ for Gadidae family (Bhowmik et al., 2017;Bianchi, Careri, Musci, \& Mangia, 2007). Meanwhile other studies reported lower natural formaldehyde content in various fish species, i.e. $0.954 ; 1.572 ; 0.964 ; 0,715$; $1.381 ; 1.303 \mathrm{ppm}, 5 \mathrm{mg} / \mathrm{kg}$ for star pompfret, barramundi, cobia, milkfish, red snapper, grouper and kerapu cantik respectively (Murtini et al., 2014; Rohmad et al., 2018). M. d. S. Hoque et al., (2018), also reported lower concentration of natural formaldehyde in Indian major carp rui, minor carp, Chinese carp and tilapia ranged from $0.77 \pm 0.03 \mathrm{mg} /$ $\mathrm{kg}$ to $1.68 \pm 0.06 \mathrm{mg} / \mathrm{kg} ; 0.43 \pm 0.03 \mathrm{mg} / \mathrm{kg}$ to $0.93 \pm 0.03$ $\mathrm{mg} / \mathrm{kg} ; 0.82 \pm 0.03 \mathrm{mg} / \mathrm{kg}$ to $1.50 \pm 0.00 \mathrm{mg} / \mathrm{kg}$; and $1.08 \pm 0.03 \mathrm{mg} / \mathrm{kg}$ to $2.08 \pm 0.05 \mathrm{mg} / \mathrm{kg}$ respectively.

Fluctuations in formaldehyde could be explained by the different levels of trimethylamine n-oxide
(TMAO) and its concentrations in fish samples. Fish storage time and temperature can play an important role in different levels of formaldehyde in fish species (Bianchi et al., 2007). The TMAO is hydrolized into trimethylamine, dimethylamine, and formaldehyde $(\mathrm{HCHO})$, whenever fish undergoes postmortem changes (Aminah, Zailina, \& Fatimah, 2013). It is known that TMAO is much more available in marine fish than in freshwater fish due to its function for the osmoregulatory system. Thus, the formaldehyde that was produced naturally in the fish muscle by either bacteria or enzyme reaction becomes covalently bonded to a cross-linkage among peptide chains (Bhowmik et al., 2017).

The chemical composition of fish meat that plays a role in the formation of formaldehyde in the fish body after death is fat and protein. According to Murtini, Wibowo, et al., (2017), with more than $20 \%$ protein content, Opah fish used in this study was classified as fish with high protein content. Furthermore, in a fish protein complex, there is TMAO degradation from choline compounds in a fish protein matrix that can decompose into formaldehyde and DMA through the regression of fish quality. Moreover, the fat content of meat is also correlated indirectly on formaldehyde formation of fish during the deterioration process through free fatty acid formation which in the later stage can be decomposed into choline and continued as TMAO. Later on, the high protein content of the opah fish samples used in this study seems to be a 
Table 2. Best fit distribution for formaldehyde concentration ( $\mathrm{mg} / \mathrm{kg}$ ) in Opah fish (Lampris guttatus) along with variation of two times and four times of formaldehyde concentration and body weight of different ages and sex

\begin{tabular}{|c|c|c|c|c|c|}
\hline Parameter & $\begin{array}{l}\text { The best fit distribution } \\
\text { function }\end{array}$ & Min & $\operatorname{Max}$ & Mean & SD \\
\hline \multicolumn{6}{|c|}{ Concentration of FA (mg/kg) } \\
\hline FA & $\begin{array}{l}\text { RiskExtvalue(22,214;14,519; } \\
\text { RiskName("FA")) }\end{array}$ & 0 & 181.38 & 30.59 & 18.62 \\
\hline FA 2 times & $\begin{array}{l}\text { RiskExtvalue(44,427;29,038; } \\
\text { RiskName("FA 2")) }\end{array}$ & 0 & 365.69 & 61.19 & 37.24 \\
\hline FA 4 times & $\begin{array}{l}\text { RiskExtvalue(88,854;58,076; } \\
\text { RiskName("FA 4")) }\end{array}$ & 0 & 782.91 & 122.38 & 74.49 \\
\hline \multicolumn{6}{|c|}{ Body Weight (kg) } \\
\hline Child Female & RiskPert $(5,9 ; 25,85 ; 54,2)$ & 6.23 & 53.24 & 27.25 & 9.07 \\
\hline Child Male & RiskPert(5,9;24,94;54,2) & 6.17 & 53.48 & 26.64 & 9.04 \\
\hline Adult Female & RiskPert(53,7;55,35;62,9) & 53.7 & 62.38 & 56.33 & 1.57 \\
\hline Adult Male & RiskPert(53,8;58,26;62,9) & 53.9 & 62.84 & 58.29 & 1.72 \\
\hline
\end{tabular}

precursor in the formation of natural formaldehyde (Murtini, Wibowo, et al., 2017).

In 2016, more than 14 ton of Opah fish which positively contained up to $91 \mathrm{ppm}$ of formaldehyde were dismissed by the regional government of DKI Jakarta (Anonymous, 2016a; Anonymous, 2016b; Anonymous, 2016c). In fact, this kind of fish can naturally contain a high concentration of formaldehyde, and even stated by Murtini et al., (2017), after several months of frozen storage, the natural formaldehyde concentration could reach $250 \mathrm{ppm}$. Based on that experience, in the present study, there are three scenarios on formaldehyde concentration to be studied i.e. the real formaldehyde content, two times of formaldehyde content and four times of formaldehyde content. Furthermore, this scenario could reach the adequate amount of 91 to $250 \mathrm{ppm}$ to demonstrate the health risk of natural formaldehyde intake by consuming opah fish.

\subsection{Formaldehyde exposure assessment}

Using the probabilistic exposure assessment in this study, one dataset for formaldehyde concentration along with the scenario of two times and four times of real formaldehyde content was constructed for Opah fish. To identify the best fit distribution in the probabilistic exposure analysis, fish consumption, body weight and natural occurrence of formaldehyde concentration in Opah fish were fitted in the
@Risk@7.0 for Microsoft Excel 2010, Palisade (2010), The best fit distributions for both of the formaldehyde concentration and body weight of consumers are shown in Table 2.

\subsubsection{Fish consumption data}

Cumulative consumption ( $\mathrm{g} /$ day BW) of Opah fish by children and adult in Jakarta and Surabaya are presented in Table 3. Fish consumption data were obtained by secondary data approach which is issued by a couple of government agencies. The calculation of consumption data is approximated by processing secondary data issued by Fish Quarantine Agency and Quality Supervisor (BKIPM) i.e. Statistics BKIPM (BKIPM, 2018) and by Ministry of Health i.e. the Individual Food Consumption Survey of 2014 data (Siswanto, 2014). Based on these approaches, Jakarta and Surabaya were chosen as the case study city, since Opah fish was distributed and consumed in both cities. The number of opah fish catch used for subsequent domestic consumption was then compared with the number of residents according to the established category (child, adult, male and female) in the areas. The result obtained is the possibility of Opah fish consumption in units ( $\mathrm{g} /$ day). Mean value of Opah fish consumption for children in Jakarta, adult in Jakarta, children in Surabaya and adult in Surabaya was 0,$16482 ; 0,22008 ; 0,17686$; and 0,23614 (g/day BW), respectively (Table 3 ). The consumption of Opah fish in Surabaya was greater 
Table 3. Consumption of Opah fish (Lampris guttatus) among children and adult in Jakarta and Surabaya

\begin{tabular}{lcc}
\hline \multicolumn{1}{c}{ Consumers } & Fish Consumption (g/day BW) & Source \\
\hline Children Jakarta & 0.16482 & \\
Adult Jakarta & 0.22008 & (BKIPM, 2018; Muljati, Triwinarto, Utami, Penelitian, \\
Children Surabaya & 0.17686 & \& Hermina, 2016; Siswanto, 2014) \\
Adult Surabaya & 0.23614 & \\
\hline
\end{tabular}

compared to consumption in Jakarta for both of children and adult. This reasonably happened because the number Opah fish that circulated in Surabaya is much higher than in Jakarta, eventhough the number of residents of Jakarta is larger rather than of Surabaya.

Based on Individual Food Consumption Survey of 2014 data (Siswanto, 2014). Jakarta and Surabaya were chosen as the case study city, since Opah fish was distributed and consumed in both cities. The number of opah fish catches used for subsequent domestic consumption was then compared with the number of residents according to the established category (child, adult, male and female) in the areas. The result obtained is the possibility of Opah fish consumption in units ( $\mathrm{g} /$ day). Mean value of Opah fish consumption for children in Jakarta, adult in Jakarta, children in Surabaya and adult in Surabaya was 0,$16482 ; 0,22008 ; 0,17686$; and 0,23614 (g/day BW), respectively (Table 3 ). The consumption of Opah fish in Surabaya was greater compared to consumption in Jakarta for both of children and adult. This reasonably happened because the number Opah fish that circulated in Surabaya is much higher than in Jakarta, eventhough the number of residents of Jakarta is larger rather than of Surabaya.

\subsubsection{Probabilistic exposure assessment}

The probabilistic dietary exposure of natural formaldehyde due to Opah fish is shown in Table 4. The data describes the formaldehyde intake from three scenarios of Opah fish formaldehyde for two locations of Jakarta and Surabaya. Each location was classified into four group based on the ages (children and adult) and the sex (male and female). Based on the data, the mean value of formaldehyde intake in Jakarta for children male, children female, adult male and an adult female was 0,$19 ; 0,20 ; 0,12$; and $0,12 \mathrm{mg} / \mathrm{kg} \mathrm{BW} /$ day, respectively. Meanwhile, the mean value of formaldehyde intake in Surabaya for children male, children female, adult male and an adult female was 0,$19 ; 0,22 ; 0,12 ;$ and $0,13 \mathrm{mg} / \mathrm{kg} \mathrm{BW} /$ day respectively.

The data on dietary exposure of formaldehyde in Surabaya were unsignificantly higher than in Jakarta, that reasonably happened due to higher consumption of consumers in Surabaya compared to in Jakarta. All residents, except children female, are considered safe to consume Opah fish from Indonesia. However, the consumers of children female in both locations of Jakarta and Surabaya were exposed to a maximum limit of average daily intake (ADI) for formaldehyde, which is only $0,20 \mathrm{mg} / \mathrm{kg} /$ day (Aminah et al., 2013). At least of $30,59 \mathrm{mg} / \mathrm{kg}$ of formaldehyde in Opah fish from Indonesia was consumed by female children in Surabaya and Jakarta which caused big risk of health concern. Furthermore, through the all further scenarios by replicating formaldehyde concentration for two times and four times (average of 61,19 and 122,38 $\mathrm{mg} / \mathrm{kg}$ respectively), the dietary exposure of formaldehyde reached 0,23 to $0,81 \mathrm{mg} / \mathrm{kg} \mathrm{BW} /$ day. Subsequently, all consumers in Jakarta and Surabaya whether children or adult, female and male, are considered as high risk for health problems by consuming Opah fish contaminated by natural formaldehyde. Eventually, the obtained data could answer the potential health risk of consuming Opah fish with the formaldehyde contamination of 91 to 250 $\mathrm{ppm}$. By assuming the same approach, those contaminated fish were considered as harmful for health concern. Thereafter, the anticipation of many stakeholders by buried the fish was good. However, as long as the fish do not reach the maximum exceeded of $15 \mathrm{mg} / \mathrm{kg}$ formaldehyde concentration, thus the Opah fish is relatively safe to be consumed.

Although the formaldehyde in Opah fish was naturally occurred, however the hazardous risk of formaldehyde for health is the same as the illegally added formaldehyde to food. Several studies on human acute toxicity revealed that formaldehyde ingestion gave serious ulceration and damage to the gastrointestinal tract. Besides, formaldehyde also causes some systemic and localized allergic reactions in human. The median lethal dose for formaldehyde has been determined to be approximately $523 \mathrm{mg} / \mathrm{kg}$ based on ingestion of a $37 \%$ solution. Endogenously, formaldehyde can cross-link proteins and singlestranded DNA, hereafter it classified as toxicokinetics. The carbonyl atom is the electrophilic site of formaldehyde, making it react easily with nucleophilic sites on cell membranes and in body fluids and tissues 
Table 4. Probabilistic dietary exposure of natural formaldehyde due to opah fish (Lampris guttatus) consumption $(\mathrm{mg} / \mathrm{kg} \mathrm{BW} /$ day) in three varieties of formaldehyde concentration

\begin{tabular}{|c|c|c|c|c|c|c|c|c|c|c|}
\hline \multirow{2}{*}{ Location } & \multirow{2}{*}{ Consumers } & \multirow{2}{*}{ Scenario } & \multicolumn{8}{|c|}{ Descriptive Level of FA Concentration (mg/kg) } \\
\hline & & & Min & Max & Mean & SD & P50 & P75 & $\mathrm{P} 90$ & P95 \\
\hline \multirow{12}{*}{ Jakarta } & \multirow{3}{*}{ Child Male } & FA & 0 & 1,49 & 0,19 & 0,12 & 0,17 & 0,25 & 0,34 & 0,40 \\
\hline & & FA 2 times & 0 & 2,57 & 0,38 & 0,23 & 0,34 & 0,50 & 0,68 & 0,81 \\
\hline & & FA 4 times & 0 & 4,68 & 0,76 & 0,46 & 0,68 & 1,00 & 1,36 & 1,62 \\
\hline & \multirow{3}{*}{ Child Female } & FA & 0 & 1,26 & 0,20 & 0,12 & 0,18 & 0,26 & 0,36 & 0,43 \\
\hline & & FA 2 times & 0 & 2,45 & 0,40 & 0,24 & 0,36 & 0,53 & 0,72 & 0,86 \\
\hline & & FA 4 times & 0 & 4,75 & 0,80 & 0,49 & 0,72 & 1,06 & 1,44 & 1,71 \\
\hline & \multirow{3}{*}{ Adult Male } & FA & 0 & 0,70 & 0,12 & 0,07 & 0,10 & 0,15 & 0,21 & 0,25 \\
\hline & & FA 2 times & 0 & 1,44 & 0,23 & 0,14 & 0,21 & 0,30 & 0,41 & 0,49 \\
\hline & & FA 4 times & 0 & 3,06 & 0,46 & 0,28 & 0,42 & 0,61 & 0,83 & 0,99 \\
\hline & \multirow{3}{*}{ Adult Female } & $\overline{F A}$ & 0 & 0,77 & 0,12 & 0,07 & 0,11 & 0,16 & 0,21 & 0,26 \\
\hline & & FA 2 times & 0 & 1,53 & 0,24 & 0,15 & 0,22 & 0,31 & 0,43 & 0,51 \\
\hline & & FA 4 times & 0 & 3,33 & 0,51 & 0,31 & 0,46 & 0,68 & 0,92 & 1,10 \\
\hline \multirow{12}{*}{ Surabaya } & \multirow{3}{*}{ Child Male } & FA & 0 & 1,18 & 0,19 & 0,12 & 0,17 & 0,25 & 0,34 & 0,40 \\
\hline & & FA 2 times & 0 & 2,39 & 0,41 & 0,25 & 0,37 & 0,54 & 0,73 & 0,87 \\
\hline & & FA 4 times & 0 & 5,47 & 0,81 & 0,49 & 0,73 & 1,07 & 1,46 & 1,73 \\
\hline & \multirow{3}{*}{ Child Female } & FA & 0 & 1,26 & 0,22 & 0,13 & 0,19 & 0,28 & 0,39 & 0,46 \\
\hline & & FA 2 times & 0 & 2,67 & 0,43 & 0,26 & 0,39 & 0,57 & 0,77 & 0,92 \\
\hline & & FA 4 times & 0 & 5,01 & 0,80 & 0,49 & 0,72 & 1,06 & 1,44 & 1,71 \\
\hline & \multirow{3}{*}{ Adult Male } & FA & 0 & 0,75 & 0,12 & 0,08 & 0,11 & 0,16 & 0,22 & 0,26 \\
\hline & & FA 2 times & 0 & 1,58 & 0,25 & 0,15 & 0,22 & 0,33 & 0,44 & 0,53 \\
\hline & & FA 4 times & 0 & 3,01 & 0,50 & 0,30 & 0,45 & 0,65 & 0,89 & 1,06 \\
\hline & \multirow{3}{*}{ Adult Female } & FA & 0 & 0,77 & 0,13 & 0,08 & 0,12 & 0,17 & 0,23 & 0,27 \\
\hline & & FA 2 times & 0 & 1,61 & 0,26 & 0,16 & 0,23 & 0,34 & 0,46 & 0,55 \\
\hline & & FA 4 times & 0 & 3,05 & 0,51 & 0,31 & 0,46 & 0,68 & 0,92 & 1,10 \\
\hline
\end{tabular}

such as the amino groups in protein and DNA. Higher concentrations of formaldehyde precipitate protein. It is probable that formaldehyde toxicity occurs when intracellular levels saturate formaldehyde dehydrogenase activity, allowing the unmetabolized intact molecule to exert its effects locally. Formaldehyde is a very strong cross-linking agent even in the low concentration range. The reaction mechanism of this agent is the initial addition of formaldehyde to a primary amine on either an amino acid residue or DNA base to yield a hydroxymethyl intermediate. Then the hydroxymethyl group condenses with a second primary amine to yield a methylene bridge. Formaldehyde is weakly genotoxic and was able to induce gene mutations and chromosomal aberrations in mammalian cells and presumably as a direct acting locally effective mutagen. The International Agency for Research on Cancer (IARC) has determined that there is sufficient evidence for the carcinogenicity of formaldehyde in humans and experimental animals. Sufficient evidence showed that formaldehyde causes nasopharyngeal cancer, sinonasal cancer, and leukemia in human. However, formaldehyde is not considered to be a reproductive or developmental toxicant (Abdollahi \& Hosseini, 2014; Aminah et al., 2013; EFSA, 2014; Tang et al., 2009; IARC, 2012; Norliana, Abdulamir, Bakar, \& Salleh, 2009).

It is important to know that these probabilistic data present description on the health risk of formaldehyde intake by consuming specifically formaldehyde contaminated-Opah fish. It means that there are many other intrinsic factors that could affect the result, especially that associated with the exposure 
assessments. Hereafter the uncertainty would arise, such as the misinterpreting on the consumption data or formaldehyde concentration that might cause underor over-estimation of dietary exposure of formaldehyde intake. Afterward, further study is needed to cover those lack of data and to consider the carcinogenic effect of formaldehyde exposure.

Considering the exposure to formaldehyde with Opah fish consumption is a possible health concern for the group of female children in Jakarta and Surabaya, furthermore, priority should be given to formulating a proper risk management strategy on the basis of knowledge of endogenous formaldehyde present in fish. The results also could be used to compare the risk of formaldehyde intake from consumption of opah fish in the present study with previous evidence, hence the stakeholders included government and policymakers could prioritize risk management strategies for the fish consumer in Indonesia.

\section{Conclusions}

In conclusion, opah fish caught in Indonesian waters could produced formaldehyde naturally due to deterioration process which ranged from 4,62 $\pm 0,00$ $\mathrm{mg} / \mathrm{kg}$ to $58,10 \pm 0,46 \mathrm{mg} / \mathrm{kg}$, less than former studies which ranged from 91 to $250 \mathrm{ppm}$. According to that range of formaldehyde concentration, the residents of female children in Jakarta and Surabaya considered as in health risk problems. Extremely, the further simulations of two times and four times of formaldehyde concentration showed the health risk to all residents in Jakarta and Surabaya included male, female, children, and adult. Assuming the similar approaches, the study could answer the health risk of opah fish that contaminated with 91 to $250 \mathrm{ppm}$ of formaldehyde, which is also considered as high health risk. However, as long as the fish do not reach the maximum exceeded of $15 \mathrm{mg} / \mathrm{kg}$ formaldehyde concentration, the opah fish is relatively safe to be consumed. Therefore, the stakeholders included government and policymakers should take some priorities to formulating a proper risk management strategy on the basis of knowledge of endogenous formaldehyde present in Opah fish and risk management strategies for the fish consumer in Indonesia.

\section{References}

Abdollahi, M., \& Hosseini, A. (2014). Formaldehyde. Encyclopedia of Toxicology, 2, 653-656. http://doi.org/ 10.1016/B978-0-12-386454-3.00388-2
Aminah, S. A., Zailina, H., \& Fatimah, A. B. (2013). Health Risk Assessment of Adults Consuming Commercial Fish Contaminated with Formaldehyde. Food and Public Health. http://doi.org/10.5923/ j.fph.20130301.06

Anonymous. (2016a). 14 TON IKAN BERFORMALIN DIMUSNAHKAN. Retrieved May 1, 2018, from http:// utara.jakarta.go.id/srv4/detail/14-Ton-IkanBerformalin-Dimusnahkan

Anonymous. (2016b). Lima Ton Ikan Semar Opah Berformalin Dikibur. Retrieved May 1, 2018, from http:/ /wartakota.tribunnews.com/2016/06/17/lima-tonikan-semar-opah-berformalin-dikibur

Anonymous. (2016c). Sebanyak 14 Ton Ikan Semar Opah Berformalin Dimusnahkan. Retrieved from http:// wartakota.tribunnews.com/2016/09/30/sebanyak14-ton-ikan-semar-opah-berformalin-dimusnahkan

Benjakul, S., Visessanguan, W., \& Tanaka, M. (2004). Induced formation of dimethylamine and formaldehyde by lizardfish (Saurida micropectoralis) kidney trimethylamine-N-oxide demethylase. Food Chemistry, 84(2), 297-305. http://doi.org/10.1016/ S0308-8146(03)00214-0

Bhowmik, S., Begum, M., Hossain, M. A., Rahman, M., \& Alam, A. K. M. N. (2017). Determination of formaldehyde in wet marketed fish by HPLC analysis: A negligible concern for fish and food safety in Bangladesh. Egyptian Journal of Aquatic Research, 43(3), 245-248. http://doi.org/10.1016/ j.ejar.2017.08.001

Bianchi, F., Careri, M., Musci, M., \& Mangia, a. (2007). Fish and Food Safety: Determination of formaldehyde in 12 fish species by SPME extraction and GC-MS analysis. Food Chemistry, 100(3), 1049-1053. http:/ /doi.org/10.1016/j.foodchem.2005.09.089

BKIPM. (2017). Prosentase Distribusi Moonfish Ekspor \& Domestik. Retrieved December 12, 2017, from www.bkipm.kkp.go.id

BKIPM. (2018). Data Lalu Lintas Ikan 2015 -2017. Retrieved February 2, 2018, from www.bkipm.kkp.go.id

EFSA. (2014). Endogenous formaldehyde turnover in humans compared with exogenous contribution from food sources. EFSA Journal, 12(2), 3550. http://doi.org/ 10.2903/j.efsa.2014.3550

Hoque, M. d. S., Jacxsens, L., Rahman, M. d. B., Nowsad, A. A. K. M., Azad, S. M. O., De Meulenaer, B., ... Rahman, M. (2018). Evaluation of artificially contaminated fish with formaldehyde under laboratory conditions and exposure assessment in freshwater fish in Southern Bangladesh. Chemosphere, 195(2018), 702-712. http://doi.org/10.1016/j.chemosphere.2017.12.111

Hoque, M. S., Jacxsens, L., De Meulenaer, B., \& Alam, A. K. M. N. (2016). Quantitative Risk Assessment for Formalin Treatment in Fish Preservation: Food Safety Concern in Local Market of Bangladesh. Procedia Food Science, 6(Icsusl 2015), 151-158. http://doi.org/ 10.1016/j.profoo.2016.02.037

IARC. (2012). Chemical agents and related occupations. IARC Monographs on the Evaluation of Carcinogenic Risks to Humans / World Health Organization, 
International Agency for Research on Cancer, 100(Pt F), 9-562. http://doi.org/now it's officially a carcinogen...

Muljati, s., triwinarto, a., utami, n., penelitian, p., \& hermina. (2016). Gambaran median tinggi badan dan berat badan menurut kelompok umur pada penduduk indonesia yang sehat berdasarkan hasil riskesdas 2013 (description of median number of weight and height classified by age group on healthy indonesian citizens based on riske. Penelitian gizi dan makanan, 39(2), 137-144.

Mundt, K. A., Gentry, P. R., Dell, L. D., Rodricks, J. V., \& Boffetta, P. (2018). Six years after the NRC review of EPA's Draft IRIS Toxicological Review of Formaldehyde: Regulatory implications of new science in evaluating formaldehyde leukemogenicity. Regulatory Toxicology and Pharmacology, 92(October 2017), 472-490. http://doi.org/10.1016/ j.yrtph.2017.11.006

Murtini, j. T., ariyani, f., januar, h. I., barokah, g. R., putri, a. K., annisah, u., ... wibowo, s. (2017). Pb formaldehid alami opah - final. Jakarta.

Murtini, j. T., riyanto, r., priyanto, n., \& hermana, i. (2014). Natural development of formaldehyde on some kinds of marine fish during storage in crushed ice. Jpb perikanan, 9, 143-151.

Murtini, j. T., wibowo, s., ariyani, f., putri, a. K., barokah, g. R., hermana, i., ... andayani, f. (2017). Laporan teknis penelitian ta. 2017, policy brief kandungan formaldehid alami pada ikan opah (lampris guttatus). Jakarta.

Nash, t. (1953). The colorimetric estimation of formaldehyde by means of the hantzsch reaction. Biochemical journal, 55(3), 416-421. Http://doi.org/ 10.1042/bj0550416

Norliana, s., abdulamir, a. S., bakar, f. A., \& salleh, a. B. (2009). The health risk of formaldehyde to human beings. American journal of pharmacology and toxicology, 4(3), 98-106.
Palisade. (2010). @RISK: Risk Analysis using Monte Carlo Simulation in Excel and Project - Palisade Palisade. Retrieved from https://www.palisade.com/ risk/default.asp\#versions

Rachmawati, N., Riyanto, R., \& Ariyani, F. (2007). Pembentukan Formaldehid Pada ikan Kerapu Macan (Ephinephelus fuscoguttatus) Selama Penyimpanan Suhu Dingin. Jurnal Pascapanen dan Bioteknologi Dan Bioteknologi Kelautan dan Perikanan, 2(2), 137-145.

Rohmad, G., Putri, A. K., Anissah, U., \& Murtini, T. (2018). Formation of Natural Formaldehyde and Deterioration of Cantik Grouper Fish (Epinephelus fuscoguttatus $\times$ E. microdon) During Frozen Storage. Jurnal Pascapanen Dan Bioteknologi Dan Bioteknologi Kelautan Dan Perikanan, 13(1), 1-8. http://doi.org/ http://dx.doi.org/10.15578/jpbkp.v13i1

Siswanto, dkk. (2014). Buku Studi Diet Total/ : Survei Konsumsi Makanan Individu Indonesia 2014. (Trihono, Atmarita, A. B. Jahari, \& D. Kartono, Eds.) (1st ed.). Jakarta: Lembaga Penerbitan Badan Litbangkes.

Tang, X., Bai, Y., Duong, A., Smith, M. T., Li, L., \& Zhang, L. (2009). Formaldehyde in China: production, consumption, exposure levels, and health effects. Environment International, 35(8), 1210-24. http:// doi.org/10.1016/j.envint.2009.06.002

Wang, S., Cui, X., \& Fang, G. (2007). Rapid determination of formaldehyde and sulfur dioxide in food products and Chinese herbals. Food Chemistry, 103(4), 14871493. http://doi.org/10.1016/j.foodchem.2006.09.023

Yeh, T.-S., Lin, T.-C., Chen, C.-C., \& Wen, H.-M. (2013). Analysis of free and bound formaldehyde in squid and squid products by gas chromatography-mass spectrometry. Journal of Food and Drug Analysis, 21(2), 190-197. http://doi.org/10.1016/j.jfda. 2013.05.010 